\title{
Article \\ The Consequences of Mechanical Vibration Exposure on the Lower Back of Bus Drivers: A Systematic Review
}

\author{
Hyago Gabriel Oliveira Mendes ${ }^{1}$, Bianca de Moraes Tomaz ${ }^{1}$, Ana Carolina Coelho-Oliveira 2,3®D, \\ Juliana Pessanha de Freitas 2,4, Márcia Cristina Moura-Fernandes 2,5, Marco Antônio de Souza-Gama 1,2, \\ Francisco José Salustiano da Silva ${ }^{1,6}$, Arlete Francisca-Santos ${ }^{1}$, Luiz Felipe Ferreira-Souza ${ }^{1,4}{ }^{\mathbb{D}}$,

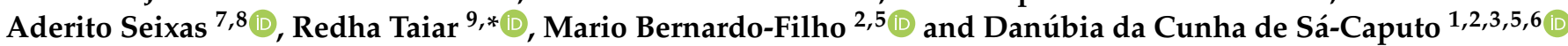

1 Laboratório de Vibrações Mecânicas e Práticas Integrativas, Faculdade Bezerra de Araújo, Rio de Janeiro 23052-180, RJ, Brazil; hyagomends@gmail.com (H.G.O.M.); bihmoraes.t@gmail.com (B.d.M.T.); drmarcogamafisioperito@gmail.com (M.A.d.S.-G.); fransalu@gmail.com (F.J.S.d.S.);

fisioarlete@gmail.com (A.F.-S.); lumadaragu@gmail.com (L.F.F.-S.); dradanubia@gmail.com (D.d.C.d.S.-C.)

2 Laboratório de Vibrações Mecânicas e Práticas Integrativas, Instituto de Biologia Roberto Alcântara Gomes and Policlínica Piquet Carneiro, Universidade do Estado do Rio de Janeiro,

Rio de Janeiro 20550-013, RJ, Brazil; anacarolcoelho26@gmail.com (A.C.C.-O.); ju.freitas.fisio@gmail.com (J.P.d.F.); marciafernandesfisio@hotmail.com (M.C.M.-F.); bernardofilhom@gmail.com (M.B.-F.)

check for updates

Citation: Mendes, H.G.O.; de Moraes Tomaz, B.; Coelho-Oliveira, A.C.; de Freitas, J.P.; Cristina Moura-Fernandes, M.; de Souza-Gama, M.A.; Salustiano da Silva, F.J.; Francisca-Santos, A.; Ferreira-Souza, L.F.; Seixas, A.; et al. The Consequences of Mechanical Vibration Exposure on the Lower Back of Bus Drivers: A Systematic Review. Appl. Sci. 2021, 11, 9986. https://doi.org/10.3390/ app11219986

Academic Editor: Claudio Belvedere

Received: 30 September 2021

Accepted: 21 October 2021

Published: 25 October 2021

Publisher's Note: MDPI stays neutral with regard to jurisdictional claims in published maps and institutional affiliations.

Copyright: (C) 2021 by the authors Licensee MDPI, Basel, Switzerland. This article is an open access article distributed under the terms and conditions of the Creative Commons Attribution (CC BY) license (https:/ / creativecommons.org/licenses/by/ $4.0 /)$.
3 Programa de Pós-Graduação em Fisiopatologia Clínica e Experimental, Faculdade de Ciências Médicas, Universidade do Estado do Rio de Janeiro, Rio de Janeiro 20550-013, RJ, Brazil

4 Mestrado Profissional em Saúde, Medicina Laboratorial e Tecnologia Forense, Instituto de Biologia Roberto Alcântara Gomes, Universidade do Estado do Rio de Janeiro, Rio de Janeiro 20550-013, RJ, Brazil

5 Programa de Pós-Graduação em Ciências Médicas, Faculdade de Ciências Médicas, Universidade do Estado do Rio de Janeiro, Rio de Janeiro 20550-013, RJ, Brazil

6 Associação Brasileira de Práticas Integrativas e Complementares, Universidade do Estado do Rio de Janeiro, Rio de Janeiro 20550-013, RJ, Brazil

7 Escola Superior de Saúde Fernando Pessoa, 4200-253 Porto, Portugal; aderito@ufp.edu.pt

8 LABIOMEP, INEGI-LAETA, Faculdade de Desporto, Universidade do Porto, 4099-002 Porto, Portugal

9 MATIM, Université de Reims, CEDEX 2, 51687 Reims, France

* Correspondence: redha.taiar@univ-reims.fr

\begin{abstract}
Professional drivers are exposed to whole-body vibration while driving, which contributes to an increased risk of developing physical problems, such as pain in the lower back. This article aims to review the effects of vibration exposure on bus drivers. Searches were performed on the PubMed, Embase, Web of Science, and Scopus databases. Only full articles of observational and experimental studies that investigated the effects of vibration on bus drivers with consequences in the lumbar region published in English were included. Data on driver demographics, study design, objectives, bus model, seat model, length of exposure to vibration, and outcomes were extracted. Two studies were classified as evidence level III-2 and three studies as level III-3. The methodological quality of the publications presented one with a moderate and four with a serious risk of bias. In all the publications, pain in the lumbar spine was reported. In conclusion, the results of this systematic review suggest that bus drivers are exposed to mechanical vibration in their work routine, and this might be considered a risk factor for the development of pain in the lumbar spine, bearing in mind that the exposure is for long periods.
\end{abstract}

Keywords: bus drivers; vibration exposure; lumbar spine; lower back

\section{Introduction}

Public transport is one of the world's most popular systems of transportation [1], playing an important role in commuting passengers across the world [2], with buses being one of the most used option [1]. Professional drivers often face severe adverse conditions, such as traffic congestion, continuous time pressure, excessive physical demands, and so 
on, which could challenge their health condition, leading to work-related musculoskeletal disorders [3,4]. The physical risk factors contributing to these musculoskeletal disorders include prolonged sitting, exposure to whole-body vibration (WBV), static or awkward postures, continuous movements, excessive forces, lack of recovery between movements, and repetitive actions [3].

According to Azenan et al. (2018) [2], bus drivers are exposed to high-intensity vibrations during their work routine, and the vibrations are considered to be etiologic agents or risk factors of occupational tasks [5]. Increased duration and intensity of the vibrations are assumed to increase risks [6]. As such, ISO 2631 of the International Organization for Standardization (ISO) [7] established standards related to human exposure to WBV. Several factors can contribute to the intensity of the vibration the driver may be exposed to, including the type and design of the vehicle [7], the engine, the seat [7], the speed at which the vehicle is moving, the body posture adopted [8], the road, and environmental issues. This intensity of vibration can be measured on three orthogonal axes, $x$-forward and backward, y-lateral, and z-vertical [2].

When driving a bus, the driver's seat receives or is exposed to vibration, and then that vibration is transmitted through the whole body of the driver. According to Blood et al. (2015) [9] and Bovenzi et al. (2009) [6], professional drivers of buses and trucks regularly spend long hours (usually $8 \mathrm{~h}$ a day) in heavy vehicles, being continuously exposed to WBV, without the possibility of stretching their body while driving. Bovenzi and Hulshof (1999) [10] suggested that vibration exposure while sitting can affect the spine due to mechanical overload and excessive muscle fatigue. Fatigue among professional drivers could be associated with the vibration transmitted to the body of the individuals [11]. It is important to emphasize that drivers carrying out a specific activity in a sitting position for a long time with constant exposure to vibration can, over the years, suffer consequences in their bodies, especially in the lower back $[8,12,13]$. In this sense, physical work has been suggested as an important predictor of LBP [14].

Thus, professional drivers constitute an occupational group that presents a high risk of developing physical issues, such as low-back pain (LBP) or lower-back pain $[15,16]$, herniated disc, and early degeneration of the spine [14,17]. Worldwide, 37\% of LBP is attributed to occupational risk factors [18]. LBP is responsible for $21 \%$ of all indemnifiable work accidents and 33\% of costs in health services [19]. The exposure to occupational vibration is one of the most common causes for lower back disorders [2,20,21], due to it being a potential stressor which can lead to the development of postural stress as a result of muscular effort and long exposure time, consequently also affecting personal, psychological, and social aspects of drivers [11,14,22]. Furthermore, according to Bovenzi and Hulshof (1999) [10], there is evidence that in occupations with exposure to WBV, LBP is the major cause of sick leave and the development of occupational illnesses.

In this context, LBP has been associated with WBV, overwork, wrong working posture, repetitive tasks, misallocation of resting and working times, lack of education about correct working posture, and job stress that can favor musculoskeletal diseases [23,24].

According to those mentioned, there is evidence for the relationship between exposure to vibration and LBP; however, little is known about the effects of vibration on bus drivers in relation to LBP. Thus, this systematic review aims to verify the effects of WBV on bus drivers and highlight the possible consequences related to LBP resulting from mechanical vibration.

\section{Methods}

This systematic review was based on the guidelines of the preferred report items for systematic reviews and meta-analyses (PRISMA) [25] and was registered on the international prospective register of systematic reviews (PROSPERO: CRD42020203294). 


\subsection{Search Strategy}

This systematic review aimed to answer the following question: Can a vehicle's vibration develop pain in the lumbar spine of a driver? The PICO search strategy ( $\mathrm{P}=$ population, $\mathrm{I}=$ intervention, $\mathrm{C}=$ comparison, and $\mathrm{O}=$ outcomes $)$ was used to define the four major components of the research question [26] as follows: $\mathrm{P}=$ bus drivers, $\mathrm{I}=$ vibration, $\mathrm{C}=$ road vehicle, and $\mathrm{O}=$ low-back pain. The literature search was conducted on June 22, 2020, using the PubMed, Embase, Web of Science, and Scopus electronic databases. The search expressions (("bus driver") AND ("pain") OR ("low-back pain") OR ("lower back") AND ("vibration")) were used in the search.

\subsection{Eligibility Criteria}

Inclusion Criteria: only full articles of observational and experimental studies that investigated the effects of vibration on bus drivers with consequences for the lower back published in English were included. No publication date restrictions were defined.

\subsection{Exclusion Criteria}

Any filters used in the search that have not been mentioned above, replies, editorials, letters, abstracts, comments, or brief communications were excluded.

\subsection{Study Selection and Data Extraction}

The references found in the databases were exported to EndNote X9 and duplicates were removed. The current systematic review was conducted following four steps. The records were identified through database search and reference screening (identification). Two reviewers (DSC, AC) independently examined the titles and abstracts of the studies, excluding any irrelevant studies (screening). All relevant articles were included following the analysis of all relevant full texts for eligibility (eligibility). Any disagreement was resolved by a third reviewer (MG). The same researchers were responsible for extracting data from the included studies. Data related to study information (author and year), driver data, study design, objectives, bus model, seat model, exposure time load, and results were extracted.

\subsection{Level of Evidence (LE)}

The LE of each article was classified according to the National Health and Medical Research Council (NHMRC) 2003-2009 [27], and the hierarchy of evidence was used to classify the studies included in this systematic review, which consists of six levels: (I) LE I—systematic review; (II) LE II-randomized controlled trial; (III) LE III1-pseudorandomized controlled trial; (IV) LE III-2 - comparative study with concurrent controls: nonrandomized experimental trial, cohort study, case-control study, interrupted time series without a parallel control group; (V) LE III-3-comparative study without concurrent controls: historical control, two or more single-arm study, interrupted time series without a parallel control group; and (VI) LE IV—cases series with either post-test or pretest/post-test outcomes.

\subsection{Risk of Bias in the Included Studies}

The risk of bias was assessed using the ACROBAT-NRSI instrument (a Cochrane risk assessment tool for nonrandomized studies), which compares the health effects of two or more interventions. ACROBAT-NRSI is divided into seven domains of having preintervention, at intervention, and postintervention criteria, with each item classified as low, moderate, serious, or critical for bias, the necessity to inform when no information is present [28].

\section{Results}

A total of 177 publications were identified through the database search (PubMed, Embase, Web of Science, and Scopus), and one article was included through other sources. 
Thirty-eight duplicate articles were excluded, leaving 140 articles for screening. During screening, 116 publications were excluded because they were not related to the subject of the current review, and 24 were considered for eligibility. After analysis, a further 19 articles were excluded. Finally, 5 articles were included in this systematic review. A flowchart according to PRISMA is presented to highlight the steps for selecting the full articles analyzed in the current systematic review (Figure 1).

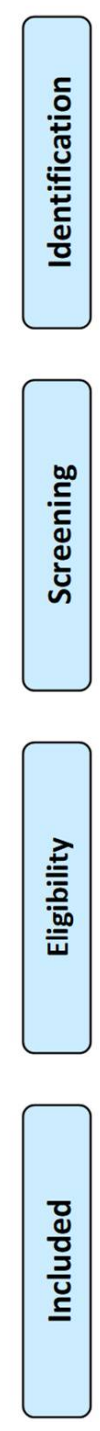

Records identified through database searching $(n=177)$

Additional records identified through other sources $(n=1)$
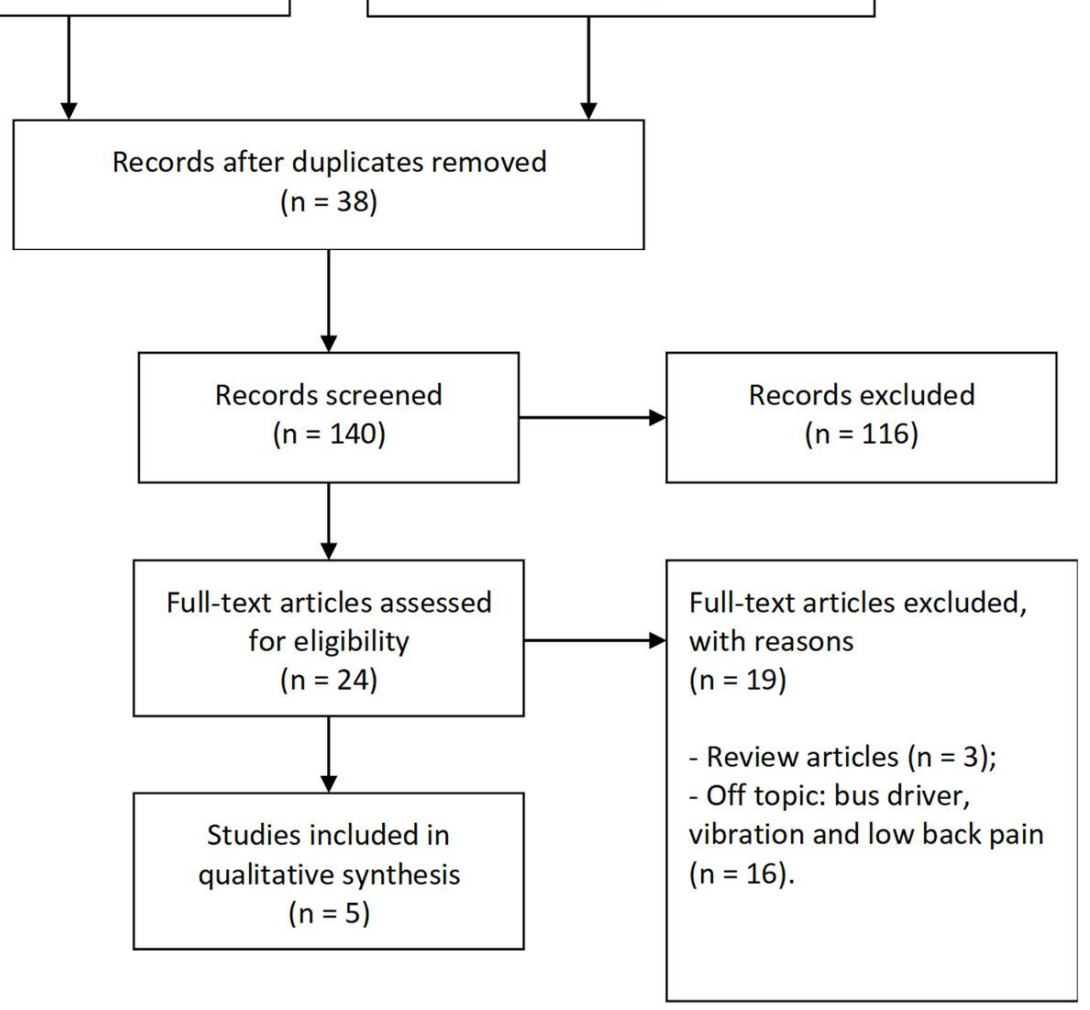

Figure 1. PRISMA flow diagram of the literature selection process.

Table 1 presents the characteristics of each study related to the type of publication, demographics, aims, results, and level of evidence of the selected publications. Among the five studies included, there were two experimental studies $[29,30]$ with a III-2 level of evidence and three cross-sectional studies $[2,31,32]$ with a III-3 level of evidence. The number of individuals in the included publications ranged from 7 to 760 participants of both sexes (men and women). The aims in the three studies $[29,31,32]$ were focused on the prevalence of LBP, and two [2,30] focused on the level of exposure to vibration. The results showed that four studies reported an association between vibration and LBP $[2,29,30,32]$ and one study did not report this association [31].

The variables evaluated in the studies were WBV, bus model, seat model, vibration measurement, and exposure time. The reported bus models varied between old buses, new buses, low-floor buses, and high-floor buses. The different models also varied according to 
the year of manufacture. Two studies reported the seat model and three studies did not. Considering the evaluation of the intensity of mechanical vibration, the studies fixed an accelerometer to the seat. Four studies $[2,29,31,32]$ used a triaxial accelerometer and one study [30] used an ICP accelerometer. The time of exposure to mechanical vibration varied from 6 to $8 \mathrm{~h}$ (Table 2).

Regarding the risk of bias, four publications [29-32] were identified as having a serious risk of bias (RoB), and one study [2] presented moderate RoB, according to our analysis based on the ACROBAT-NRSI instrument. These results are shown in Figure 2.

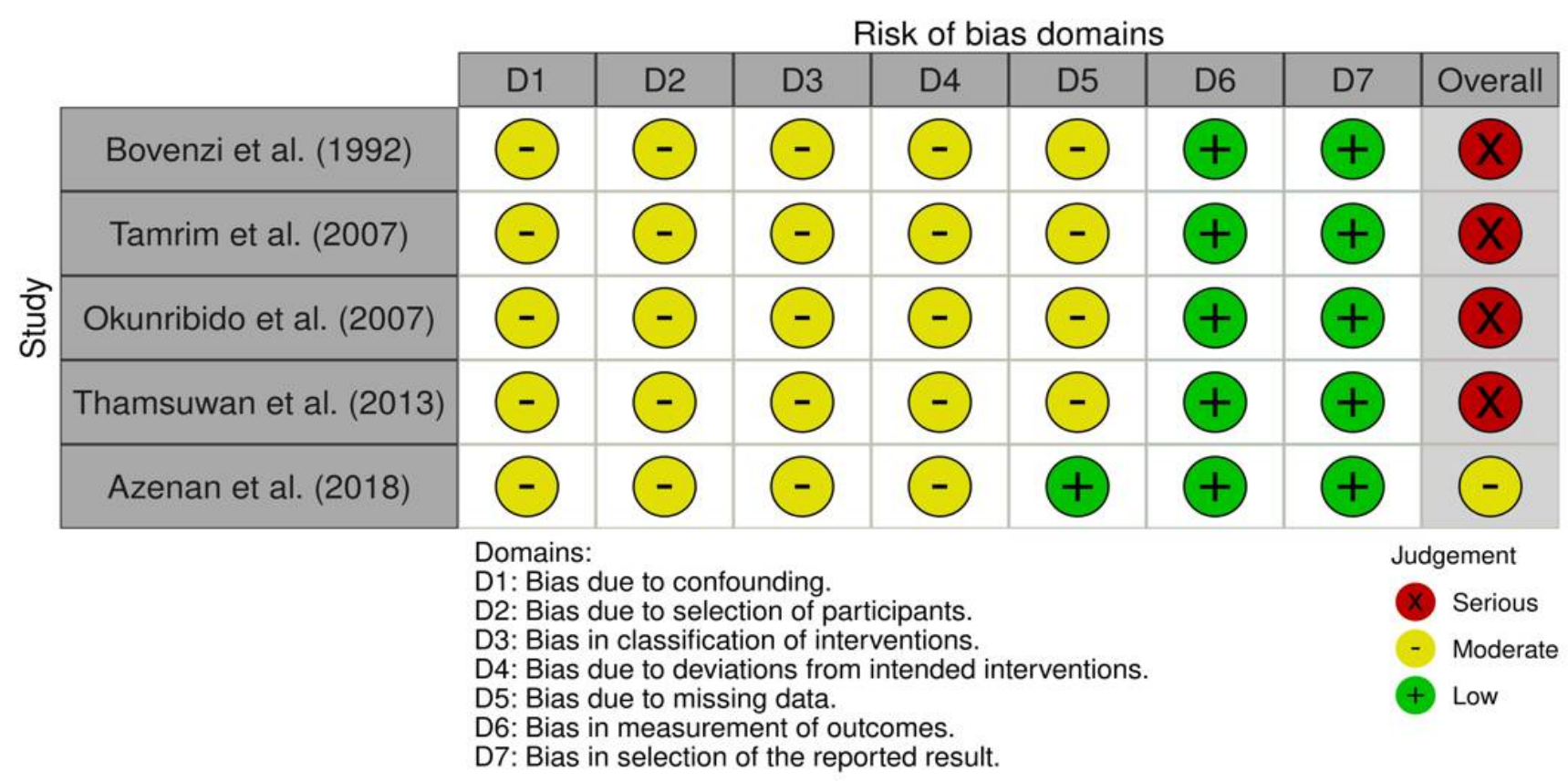

Bias due to confounding

Bias due to selection of participants

Bias in classification of interventions

Bias due to deviations from intended interventions

Bias due to missing data

Bias in measurement of outcomes

Bias in selection of the reported result

Overall risk of bias

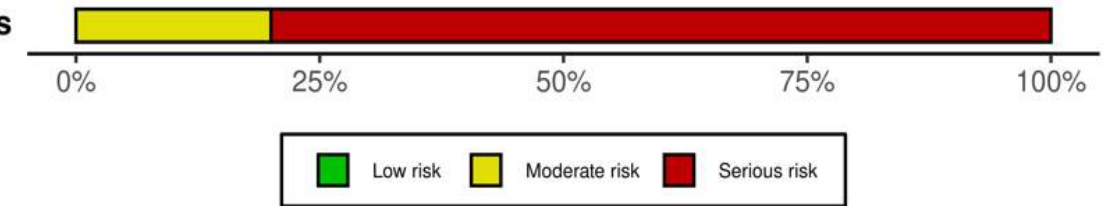

Figure 2. ACROBAT-NRSI risk of bias. 
Table 1. Characteristics of the included studies and the level of evidence.

\begin{tabular}{|c|c|c|c|c|c|}
\hline Study & Study Design & Demographics & Aim & Results & LE \\
\hline Bovenzi et al., 1992 & Experimental study & $\begin{array}{l}234 \text { drivers (male) } \\
\text { Age: } 41.2 \text { years } \\
125 \text { control workers } \\
\text { Age: } 44.5 \text { years }\end{array}$ & $\begin{array}{l}\text { To analyze the prevalence of } \\
\text { severe types of LBP among } \\
\text { bus drivers employed in a } \\
\text { municipal public transport } \\
\text { company. }\end{array}$ & $\begin{array}{l}\text { The findings also indicated that among bus } \\
\text { drivers, lumbar symptoms occurred at levels of } \\
\text { exposure to WBV below the health exposure } \\
\text { limits proposed by the International Standard } \\
\text { ISO } 2631 / 1 \text {. }\end{array}$ & III-2 \\
\hline Tamrin et al., 2007 & $\begin{array}{l}\text { Cross-section of a cohort } \\
\text { study }\end{array}$ & $\begin{array}{l}760 \text { drivers (male) from } 11 \text { bus } \\
\text { companies }\end{array}$ & $\begin{array}{l}\text { To determine the prevalence } \\
\text { of musculoskeletal disorders, } \\
\text { including LBP, and reveal the } \\
\text { physical and psychological } \\
\text { risk factors. }\end{array}$ & $\begin{array}{l}\text { This study revealed no significant association } \\
\text { between WBV exercise and LBP and } \\
\text { demonstrated that the risk factors for } \\
\text { developing LBP do not depend on just one } \\
\text { factor (physical and psychological). }\end{array}$ & III-3 \\
\hline Okunribido et al., 2007 & Cross-sectional study & $\begin{array}{c}61 \text { drivers ( } 58 \text { men and } 3 \text { women), } \\
\text { Age: } 19 \text { to } 64 \text { years } \\
\text { Body mass: between } \\
58.6-129.0 \mathrm{~kg} \text { (mean } 84.9 \mathrm{~kg} \text {, SD } \\
15.72) \\
\text { Height: between } 154.9 \text { and } \\
192.0 \mathrm{~cm} \text { in height }\end{array}$ & $\begin{array}{l}\text { To investigate the typical } \\
\text { exposures of urban bus } \\
\text { drivers to the demands of } \\
\text { posture when driving, } \\
\text { manual material handling } \\
\text { and vibration, as well as the } \\
\text { prevalence and nature of LBP. }\end{array}$ & $\begin{array}{l}\text { City bus drivers spend about } 60 \% \text { of their daily } \\
\text { work time driving, often with the torso straight } \\
\text { or unsupported, perform occasional and light } \\
\text { manual material handling, and experience } \\
\text { discomforting shock/jerking vibration events. } \\
\text { Transient and mild LBP (not likely to interfere } \\
\text { with work or customary levels of activity) was } \\
\text { found to be prevalent among the drivers, and a } \\
\text { need for ergonomic evaluation of the drivers' } \\
\text { seats was suggested. }\end{array}$ & III-3 \\
\hline Thamsuwan et al., 2013 & Experimental study & $\begin{array}{l}\text { Low floor: } 15 \text { drivers }(13 \text { men } \\
\text { and } 2 \text { women) } \\
\text { Mean age: } 42.3 \text {; Mean body mass: } \\
93.7 \mathrm{~kg} \text {; Mean height: } 176.8 \mathrm{~cm} \text {; } \\
\text { Mean BMI: } 30.0 \mathrm{~kg} / \mathrm{m}^{2} . \text { High } \\
\text { floor: } 12 \text { drivers }(8 \text { men and } \\
4 \text { women) } \\
\text { Mean age: } 42.8 \text {; Mean body mass: } \\
94.2 \mathrm{~kg} \text {; Mean height: } 169.9 \mathrm{~cm} \text {; } \\
\text { Mean BMI: } 32.5 \mathrm{~kg} / \mathrm{m}^{2}\end{array}$ & $\begin{array}{l}\text { To determine if there are } \\
\text { differences in performance } \\
\text { between the two buses on the } \\
\text { road and the traffic } \\
\text { conditions that are } \\
\text { encountered during normal } \\
\text { operation. }\end{array}$ & $\begin{array}{l}\text { WBV exposures were significantly different } \\
\text { between road types, both on high-floor and } \\
\text { low-floor buses. The WBV exposures on the } \\
\text { high-floor bus were slightly smaller than the } \\
\text { low-floor bus exposures when driving on } \\
\text { smooth highways and city streets. In contrast, } \\
\text { on the high-floor bus, the WBV exposures were } \\
\text { substantially larger than the low-floor bus } \\
\text { exposures when driving on the bumpy road } \\
\text { segment. }\end{array}$ & III-2 \\
\hline
\end{tabular}


Table 1. Cont.

\section{Study}

Study Design

Demographics

\section{2 drivers}

Azenan et al., 2018

Cross-sectional study
(5 bus drivers from Putrajaya

Sentral and 7 bus drivers from Larkin Central
To identify the level of WBV

among bus drivers and assess whether exposure to

vibration has already

exceeded the exposure limit

based on ISO 2631/1.

\section{Results}

Upper back pain and LBP were identified as significant effects of vibration. The results

showed a positive, strong, and significant

relationship between daily exposure to vibration and upper and lower back pain. The Larkin

Central drivers were exposed to significantly

higher vibration that exceeds the exposure limit when compared to those at Putrajaya Sentral.

Legend: BMI—body mass index, ISO—International Organization for Standardization, WBV—whole-body vibration; LBP—low-back pain; SD—standard deviation; LE—level of evidence.

Table 2. Characteristics of mechanical vibration exposure.

\begin{tabular}{|c|c|c|c|c|c|}
\hline Study & $\begin{array}{c}\text { Variables Measured by } \\
\text { WBV }\end{array}$ & BUS MODEL & Seat Model & Vibration Measurement & Exposure Time \\
\hline Bovenzi et al., 1992 & $\begin{array}{c}\text { Standardized questionnaire } \\
\text { on musculoskeletal } \\
\text { symptoms }\end{array}$ & $\begin{array}{c}3 \text { old buses: Fiat } 409 \text { DSU, } \\
\text { Fiat } 410 \text { P, Fiat } 418 \text { AL } \\
\text { (1968-1973) } \\
3 \text { new buses: Inbus U-210 } \\
\text { FTN, Iveco U-F1, Iveco } \\
\text { Turbocity-U (1987-1990) }\end{array}$ & $\begin{array}{l}\text { Not } \\
\text { reported }\end{array}$ & $\begin{array}{c}\text { Bruel \& Kjaer triaxial seat } \\
\text { accelerometer (B\&K 4322, } \\
\text { Denmark), compatible with ISO } \\
\text { 2631-1. The average magnitude } \\
\text { of vertical vibration of the entire } \\
\text { body measured was } 0.4 \mathrm{~m} / \mathrm{s}^{2} \text {. }\end{array}$ & $\begin{array}{l}\text { For vibration analysis: each } \\
\text { measured vibration lasted } \\
\text { from } 15 \text { to } 20 \text { min. } \\
\text { Daily exposure value: } 6 \mathrm{~h} \text { and } \\
10 \text { min. }\end{array}$ \\
\hline Tamrin et al., 2007 & $\begin{array}{l}\text { LBP and work factor, } \\
\text { postural analysis, } \\
\text { mood state. }\end{array}$ & Not reported & Not reported & $\begin{array}{c}\text { Maestro human vibration meter } \\
\text { (01DB-Metravib }{ }^{\circledR}, \text { Lyon, France) } \\
\text { with a triaxial accelerometer } \\
(0.4-1000 \mathrm{~Hz}), \text { compatible with } \\
\text { ISO 2631-1. } \\
\text { Movements analyzed during } \\
\text { travel: } \\
\text { (1) forward bending, } \\
\text { (2) inclined, } \\
\text { (3) sitting straight, and } \\
\text { (4) twisted. }\end{array}$ & $\begin{array}{c}\text { Each driver drove a different } \\
\text { bus and made different } \\
\text { routes on different days. } \\
\text { For vibration analysis: } \\
\text { The total duration of } 25 \mathrm{~min} \\
\text { with an interval of } 1 \mathrm{~s} \text { for data } \\
\text { recording. } \\
\text { The action level for } 25 \mathrm{~min} \\
\text { was } 2.18 \mathrm{~m} / \mathrm{s}^{2} \text { and the } \\
\text { r.ms-exposure limit-for } \\
25 \text { min was } 5.02 \mathrm{~m} / \mathrm{s}^{2} \text {. } \\
\text { Daily exposure value: } 8 \mathrm{~h} \text {. }\end{array}$ \\
\hline
\end{tabular}


Table 2. Cont.

\begin{tabular}{|c|c|c|c|c|c|}
\hline Study & $\begin{array}{c}\text { Variables Measured by } \\
\text { WBV }\end{array}$ & BUS MODEL & Seat Model & Vibration Measurement & Exposure Time \\
\hline Okunribido et al., 2007 & $\begin{array}{c}\text { Self-evaluation: } \\
\text { questionnaires about LBP } \\
\text { experience when driving } \\
\text { (sitting), posture, and manual } \\
\text { material handling. }\end{array}$ & $\begin{array}{c}\text { One-story Volvo B10BLE } \\
\text { Wright Renown; one-story } \\
\text { Volvo B10BLE Alexander } \\
\text { ALX300; articulated } \\
\text { single-deck Volvo B7LA } \\
\text { Wright Eclipse; Leyland } \\
\text { Olympian Alexander R } \\
\text { two-story; Volvo B7TL } \\
\text { Alexander ALX400 } \\
\text { double-decker; Mercedes } \\
\text { 709D Alexander AM minibus; } \\
\text { Volvo B10 M Plaxton } \\
\text { Premiere 3.5; Volvo B6, and } \\
\text { Coach Plaxton Paramount. }\end{array}$ & $\begin{array}{l}\text { Mercedes 709D Alexander } \\
\text { AM minibus = } 23 \text { Beaver } \\
\text { seats. The other types of seats } \\
\text { were not informed. }\end{array}$ & $\begin{array}{l}\text { Liberty Mutual } 2.0 \text { full body } \\
\text { vibration meter } \\
\text { using a triaxial seat } \\
\text { accelerometer, which was placed } \\
\text { in the seat below the driver's } \\
\text { ischial tuberosities when seated } \\
\text { and connected to a portable field } \\
\text { computer packaged in a robust } \\
\text { instrument. }\end{array}$ & $\begin{array}{l}\text { Service route driving } \\
\text { throughout at least one } \\
\text { complete round trip. } \\
\text { Observation times } \\
\text { varied between } 1 \mathrm{~h} 21 \mathrm{~min} \\
\text { and } 1 \mathrm{~h} 44 \text { min. } \\
\text { Daily exposure value: } 7 \mathrm{~h} \\
36 \text { min. }\end{array}$ \\
\hline Thamsuwan et al., 2013 & Different types of highways & $\begin{array}{c}\text { Low floor: } \\
\text { model D40LF; New Flyer; } \\
\text { Winnipeg, Manitoba } \\
12.2 \text { m in length (7 years) } \\
\text { High floor: model D4500; } \\
\text { Motor Coach Industries Inc; } \\
\text { Winnipeg, Manitoba } \\
\text { 13.9 m in length (5 years) }\end{array}$ & Model Q91; USSC; Exton, PA & $\begin{array}{l}\text { Four-channel data recorder } \\
\text { (model DA-20; Rion Co., Ltd.; } \\
\text { Tokyo, Japan). Gross unweighted } \\
\text { triaxial WBV measurements were } \\
\text { collected at } 1280 \mathrm{~Hz} \text { per channel } \\
\text { using a seat cushion ICP } \\
\text { accelerometer (model 356B40; } \\
\text { PCB Piezotronics; Depew, NY, } \\
\text { USA) mounted on the driver's } \\
\text { seat. In addition, once a second, a } \\
\text { global positioning system (model } \\
\text { DG-100; GlobalSat; Chino, CA, } \\
\text { USA) collected GPS data to } \\
\text { record location and speed. }\end{array}$ & $\begin{array}{l}\text { Different drivers had to } \\
\text { operate each bus. } \\
\text { All participants drove on the } \\
\text { same standardized test route, } \\
\text { which took about } 75 \text { min to } \\
\text { complete. } \\
\text { Daily exposure value: } 8 \mathrm{~h} \text {. }\end{array}$ \\
\hline Azenan et al., 2018 & $\begin{array}{l}\text { Modified Nordic } \\
\text { questionnaire (screening for } \\
\text { musculoskeletal disorders } \\
\text { and pain) }\end{array}$ & Not reported & Not reported & $\begin{array}{c}\text { Human vibration meter } \\
\text { instruments (HVM100 Larson } \\
\text { Davis) and a triaxial seat cushion } \\
\text { accelerometer. } \\
\text { Each HVM } 100 \text { record = up to } 4 \\
\text { min. }\end{array}$ & $\begin{array}{l}\text { Vibration measurement time: } \\
\text { Putrajaya Sentral was } 36 \mathrm{~min} \\
\text { and Larkin Central } 40 \mathrm{~min} . \\
\text { Daily exposure value: } 8 \mathrm{~h} .\end{array}$ \\
\hline
\end{tabular}

Legend: WBV—whole-body vibration; ISO—International Organization for Standardization, LBP—low-back pain. 


\section{Discussion}

This systematic review aimed to assess exposure to mechanical vibration and its association with lumbar symptoms of bus drivers in different situations. It was possible to observe the influence of vibration on LBP in bus drivers through factors such as several levels of exposure to vibration, long hours and routine exposure to vibration, inadequate posture used by drivers when driving, psychological factors related to work, and the various types of roads that bus drivers use during their journeys. It is important to highlight that LBP was reported in four of the five studies.

All the selected publications followed the recommendations of the ISO 2631 standard, which regulates human exposure to $\mathrm{WBV}$, and performed vibration measurements. Different levels of vibration were described in the publications of the current systematic review. Nevertheless, the levels of exposure to vibration reported by Okunribido et al. (2007) [32]; Azenan et al. (2018) [2]; and Thamsuwan et al. (2013) [30] were considered high, considering the ISO 2631 standards. In this context, Bovenzi and Zadini (1992) [29] reported that higher total doses of vibration are strongly related to all types of lumbar symptoms and disc protrusion.

Additionally, considering that the level of exposure to vibration varies depending on the place and the company, Okunribido et al. (2007) [32] suggested that there may be exposure to uncomfortable levels of vibratory stress in bus drivers, whereby the vibration received by the bus driver can promote effects on the lumbar spine, with there being a high risk and a relationship between the vibration and exposure of these drivers. Bovenzi and Zadini (1992) [29] reported that exposure to vibration is a significant indicator of low-back problems among bus drivers. Accordingly, Azenan et al. (2018) [2] stated that there was a positive, strong, and significant relationship between daily exposure to vibration and upper and lower back pain. However, Tamrin et al. (2007) [31] did not report a significant association between exposure to WBV and LBP. Therefore, it is not yet possible to define whether LBP would be directly associated with exposure to vibration. Bovenzi and Zadini (1992) [29] suggested that the high risk for low-back problems is related to driving a bus and that there is an increase in the prevalence of most lumbar complaints with an increase in the total dose of vibration. Thus, vibration would be a factor that can significantly affect drivers. Other factors, such as conditions and type of road, can also influence lumbar symptoms, together with vibration. Thamsuwan et al. (2013) [30] reported that the vibration exposures were significantly different between the types of roads, often due to their conditions and imperfections, along the route, which may affect the drivers and increase how they feel the vibration. In this sense, Thamsuwan et al. (2013) [30]; Tamrin et al. (2007) [31]; and Okunribido et al. (2007) [32] studied the vibration on different roads consisting of smooth road, bumpy road, city street, and speed bumps, and whether the area was urban, suburban, agrarian, residential, or industrial. It was verified that the parameters of WBV were higher on the road with speed bumps and lower on the smooth road, even though different types of buses and seats were used in the studies.

As previously mentioned, posture at work is also a factor that can negatively influence the daily life of bus drivers [33] including lumbar symptoms [8,19]. Corroborating this statement, Bovenzi and Zadini (1992) [29] B and Tamrin et al. (2007) [31] reported that frequent inappropriate postures were significantly related to certain types of lumbar symptoms. Blood et al. (2015) [9] also observed a significant effect on the results between posture and exposure to $\mathrm{WBV}$, given the posture acquired by the bus driver, reflecting in how they feel the vibration and possibly causing negative results. Therefore, Azenan et al. (2018) [2] suggested that inappropriate postures, together with vibration, would amplify exposure to WBV. Therefore, it is important to consider that although posture alone may or may not affect the lower back, the addition of vibration can help trigger lower back symptoms.

Psychological factors are poorly reported in the studies and may have a direct or indirect relationship with mechanical vibration and other factors for lumbar symptoms. Tamrin et al. (2007) [31] reported a significant association between negative moods and 
LBP caused by a high level of stress, since bus drivers must meet schedules, provide good service to passengers, adhere to safe driving practices, and withstand peak traffic conditions. In other studies, Alperovitch-Najenson et al. (2010) [34] stated that stressful and psychosocial ergonomic factors, as well as a lack of a sports activity, are associated with LBP in professional urban bus drivers. Similarly, Pope et al. (2002) [19] suggested that psychosocial factors can influence disability and LBP.

Among the included publications, Bovenzi and Zadini (1992) [29]; Tamrin et al. (2007) [31]; Okunribido et al. (2007) [32]; and Azenan et al. (2018) [2] used questionnaires to assess the drivers' routine. Among the factors reported as the cause of LBP, it was suggested that fatigue can be caused by the mechanical vibration received throughout the daily work routine. Tamrin et al. (2007) [31] reported a significant relationship between fatigue and LBP, as did Tiemessen et al. (2007) [15], who found that exposure to vibration can induce fatigue and depletion of the paravertebral muscles of the lumbar region. In addition and agreement, Bovenzi and Zadini (1992) [29] performed electromyographic measurements of the back muscles during the vertical vibration felt by the drivers, and observed that the increased muscle tension increases the load on the vertebral bodies and discs, causing fatigue and pain. Moreover, it was reported that vibration-induced muscle fatigue has a conditioning effect, resulting in increased susceptibility of the spine to injury.

Bovenzi and Zadini (1992) [29] concluded that there is a significant indicator of lumbar problems between exposure to WBV and bus drivers, which corroborates the studies by Bovenzi and Hulshof (1998) [10] and Tiemessen et al. (2007) [15]. Azenan et al. (2018) [2] and Jonsson et al. (2015) [7] described several causes of LBP, such as speed, vehicle design, and environmental conditions. Thamsuwan et al. (2013) [30] and Tamrin et al. (2007) [31] reported that the body posture of the driver was also one of the causes that influenced the transmissibility of the vibration. Sinczuk-Walczak et al. (2015) [13] reported that evidenced nervous system disorders indicate the need to undertake preventive measures tailored for bus drivers. Simões et al. (2019) [35] described worse health, mainly common mental disorders, was associated with self-assessed work precariousness as reported by bus drivers and conductors. LBP has been also found in taxi drivers (prevalence of $27.9 \%$ ) through self-reported LBP in the past 12 months. Yosef et al. (2019) [36] interviewed 400 truck drivers to assess the magnitude of LBP in these individuals and a prevalence of $65 \%$ was found. Ghasemi et al. (2020) [37] studied the impact of rest breaks and stretching exercises on commercial truck drivers, and reported that these individuals presented a reduction in LBP and disability due to the use of supplementary exercises during break periods.

Regarding the limitations of this systematic review, different methods were used for the evaluation of mechanical vibration exposition, only four databases were used, only publications in English were considered, and different types of vehicles and designs were observed. Furthermore, control groups were not included in the five studies, and X-rays of the lumbar spine were not assessed. Consequently, according to the overall RoB judgment, the articles included in this review were, in general, at a serious risk of bias.

The strength of this systematic review is related to the finding that being a bus driver could be a risk factor to the development of pain in the lumbar spine. In addition, it is important for companies to support drivers by establishing partnerships with health agencies focused on medicine, psychology, nutrition, physiotherapy, and other services to aid drivers. Furthermore, for prevention, the companies could (i) perform weekly followups with bus drivers to prevent lumbar spine impact; (ii) provide proper bus maintenance; and (iii) limit the length of vibration exposure time to minimize the impact on bus drivers. Moreover, this information on bus drivers may be important to policies involving drivers in agriculture and forestry, on diggers, in road construction, or on military vehicles.

\section{Conclusions}

The findings of the current systematic review suggest that the exposure of bus drivers to vibration in the work routine may be considered a risk factor to the development of pain in the lumbar spine. It is suggested that posture, psychological factors, the conditions 
and road, and the exposure to vibration may be related to LBP in bus drivers. For better understanding of the effects of mechanical vibration exposure during the daily work routine of bus drivers that might lead to LBP, more studies with better methodological quality are necessary.

Author Contributions: Conceptualization, H.G.O.M. and B.d.M.T.; Methodology, A.C.C.-O. and M.A.d.S.-G.; Formal analysis, R.T. and M.B.-F.; Investigation, D.d.C.d.S.-C.; Writing-original draft preparation, H.G.O.M., B.d.M.T., A.C.C.-O., M.C.M.-F. and J.P.d.F.; Writing-review and editing, A.C.C.-O., F.J.S.d.S. and A.F.-S.; Supervision, M.B.-F.; Review and editing, L.F.F.-S. and A.S. All authors have read and agreed to the published version of the manuscript.

Funding: This research received no external funding.

Conflicts of Interest: The authors declare no conflict of interest.

\section{References}

1. Figueiredo, M.A.D.M.; Silva, L.F.; Barnabé, T.L. Transporte coletivo: Vibração de corpo-inteiro e conforto de passageiros, motoristas e cobradores. J. Transp. Lit. 2016, 10, 35-39. [CrossRef]

2. Azenan, A.F.; Azlis-Sani, J. Effects of vibration on intrastate bus drivers. J. Phys. Conf. Ser. 2018, 1049, 012094. [CrossRef]

3. Joseph, L.; Vasanthan, L.; Standen, M.; Kuisma, R.; Paungmali, A.; Pirunsan, U.; Sitilertpisan, P. Causal relationship between the risk factors and work-related musculoskeletal disorders among professional drivers: A Systematic Review. Hum. Factors J. Hum. Factors Ergon. Soc. 2021. [CrossRef] [PubMed]

4. Montoro, L.; Useche, S.; Alonso, F.; Cendales, B. Work environment, stress, and driving anger: A structural equation model for predicting traffic sanctions of public transport drivers. Int. J. Environ. Res. Public Health 2018, 15, 497. [CrossRef] [PubMed]

5. World Health Organization. Occupational Health; World Health Organization: Geneva, Switzerland, 1978.

6. Bovenzi, M. Metrics of whole-body vibration and exposure-response relationship for low back pain in professional drivers: A prospective cohort study. Int. Arch. Occup. Environ. Health 2008, 82, 893-917. [CrossRef] [PubMed]

7. Jonsson, P.M.; Rynell, P.W.; Hagberg, M.; Johnson, P.W. Comparison of whole-body vibration exposures in buses: Effects and interactions of bus and seat design. Ergonomics 2014, 58, 1-10. [CrossRef]

8. Arma, M.; Septadina, I.S.; Legiran, L. Factors affecting low back pain (lbp) among public transportation drivers. Maj. Kedokt. Sriwij. 2019, 51, 206. [CrossRef]

9. Blood, R.P.; Yost, M.G.; Camp, J.E.; Ching, R.P. Whole-body vibration exposure intervention among professional bus and truck drivers: A laboratory evaluation of seat-suspension designs. J. Occup. Environ. Hyg. 2015, 12, 351-362. [CrossRef]

10. Bovenzi, M.; Hulshof, C.T.J. An updated review of epidemiologic studies on the relationship between exposure to whole-body vibration and low back pain (1986-1997). Int. Arch. Occup. Environ. Health 1999, 72, 351-365. [CrossRef]

11. Ferreira-Souza, L.F.; Gama, M.A.S.; Coelho-Oliveira, A.C.; Sá-Caputo, D.C.; Bernardo-Filho, M. Could Whole-body vibration lead the professional drivers to fatigue? Narrat. Rev. J. Ergon. 2021, 11, 272.

12. Verma, G.; Tiwari, R.; Verma, A.; Bharath, C.S.; Tomar, S. Occupational lower back pain among bus conductors of Udupi district, Karnataka. Int. J. Occup. Saf. Ergon. 2020, 1-5. [CrossRef] [PubMed]

13. Sińczuk-Walczak, H.; Siedlecka, J.; Szymczak, W.; Gadzicka, E.; Walczak, A.; Kowalczyk, G.; Dania, M.; Bortkiewicz, A. Neurological symptoms and syndromes in municipal transport drivers. Med. Pract. 2015, 66, 333-341. [CrossRef]

14. Bovenzi, M. A longitudinal study of low back pain and daily vibration exposure in professional drivers. Ind. Health 2010, 48 , 584-595. [CrossRef] [PubMed]

15. Tiemessen, I.J.H.; Hulshof, C.T.J.; Frings-Dresen, M.H.W. Low back pain in drivers exposed to whole body vibration: Analysis of a dose-response pattern. Occup. Environ. Med. 2008, 65, 667-675. [CrossRef]

16. Yitayal, M.M.; Sileshi, A.; Fiseha, B.; Kahasay, G.; Gashew, M.; Gebre, H. Occupational lower back pain and associated factors among taxi drivers in Mekelle city, North, Ethiopia: A cross-sectional study. Int. J. Occup. Saf. Ergon. 2021, 1-20. [CrossRef] [PubMed]

17. Comité Européen de Normalisation. Mechanical Vibration-Guide to the Health Effects of Vibration on the Human Body; CR Report 12349; CEN: Brussels, Belgium, 1996.

18. Punnett, L.; Prüss-Ütün, A.; Nelson, D.I.; Fingerhut, M.A.; Leigh, J.; Tak, S.; Phillips, S. Estimating the global burden of low back pain attributable to combined occupational exposures. Am. J. Ind. Med. 2005, 48, 459-469. [CrossRef]

19. Pope, M.H.; Goh, K.L.; Magnusson, M.L. Spine ergonomics. Annu. Rev. Biomed. Eng. 2002, 4, 49-68. [CrossRef]

20. Bovenzi, M.; Schust, M.; Mauro, M. An overview of low back pain and occupational exposures to whole-body vibration and mechanical shocks. Med. Lav. 2017, 108, 419-433. [CrossRef]

21. Moraes, G.F.S.; Sampaio, R.F.; Silva, L.F.; Souza, M.A.P. Whole-body vibration and musculoskeletal diseases in professional truck drivers. Fisioter. Movimento 2016, 29, 159-172. [CrossRef]

22. Lyons, J. Factors contributing to low back pain among professional drivers: A review of current literature and possible er-gonomic controls. Work 2002, 19, 95-102. 
23. Lee, J.-H.; Gak, H.B. Effects of self stretching on pain and musculoskeletal symptom of bus drivers. J. Phys. Ther. Sci. 2014, 26, 1911-1914. [CrossRef]

24. Maher, C.; Underwood, M.; Buchbinder, R. Non-specific low back pain. Lancet 2017, 389, 736-747. [CrossRef]

25. Moher, D.; Liberati, A.; Tetzlaff, J.; Altman, D.G.; Altman, D.; Antes, G.; Atkins, D.; Barbour, V.; Barrowman, N.; Berlin, J.A.; et al. Preferred reporting items for systematic reviews and meta-analyses: The PRISMA statement. PLoS Med. 2009, 339 , b2535. [CrossRef]

26. Liberati, A.; Altman, D.G.; Tetzlaff, J.; Mulrow, C.; Gøtzsche, P.C.; A Ioannidis, J.P.; Clarke, M.; Devereaux, P.; Kleijnen, J.; Moher, D. The PRISMA statement for reporting systematic reviews and meta-analyses of studies that evaluate healthcare interventions: Explanation and elaboration. J. Clin. Epidemiol. 2009, 62, e1-e34. [CrossRef]

27. Merlin, T.; Weston, A.; Tooher, R. Extending an evidence hierarchy to include topics other than treatment: Revising the Australian 'levels of evidence'. BMC Med. Res. Methodol. 2009, 9, 34. [CrossRef]

28. Thomson, H.; Sterne, J.; Higgins, J. ACROBAT-NRSi (A Cochrane Risk of Bias Assessment Tool: For Non-Randomized Studies of Interventions) for Non-Clinical Community Based Studies: A Participatory Workshop Using A Worked Example From Public Health. In Filtering the Information Overload for Better Decisions; Abstracts of the 23rd Cochrane Colloquium; Vienna, Austria. 2015. Available online: https:/ / abstracts.cochrane.org/2015-vienna/acrobat-nrsi-cochrane-risk-bias-assessment-toolnon-randomized-studies-interventions-non (accessed on 20 October 2021).

29. Bovenzi, M.; Zadini, A. Self-reported low back symptoms in urban bus drivers exposed to whole-body vibration. Spine 1992, 17, 1048-1059. [CrossRef]

30. Thamsuwan, O.; Blood, R.P.; Ching, R.P.; Boyle, L.; Johnson, P.W. Whole body vibration exposures in bus drivers: A comparison between a high-floor coach and a low-floor city bus. Int. J. Ind. Ergon. 2013, 43, 9-17. [CrossRef]

31. Tamrin, S.B.M.; Yokoyama, K.; Jalaludin, J.; Aziz, N.A.; Jemoin, N.; Nordin, R.; Naing, A.L.; Abdullah, Y.; Abdullah, M. The Association between Risk Factors and Low Back Pain among Commercial Vehicle Drivers in Peninsular Malaysia: A Preliminary Result. Ind. Health 2007, 45, 268-278. [CrossRef] [PubMed]

32. Okunribido, O.O.; Shimbles, S.J.; Magnusson, M.; Pope, M. City bus driving and low back pain: A study of the exposures to posture demands, manual materials handling and whole-body vibration. Appl. Ergon. 2006, 38, 29-38. [CrossRef] [PubMed]

33. Krajnak, K. Health effects associated with occupational exposure to hand-arm or whole body vibration. J. Toxicol. Environ. Health Part. B 2018, 21, 320-334. [CrossRef] [PubMed]

34. Alperovitch-Najenson, D.; Santo, Y.; Masharawi, Y.; Katz-Leurer, M.; Ushvaev, D.; Kalichman, L. Low back pain among profes-sional bus drivers: Ergonomic and occupational-psychosocial risk factors. Isr. Med Assoc. J. 2010, 12, 26-31. [PubMed]

35. Simões, M.R.L.; Souza, C.; De Alcantara, M.A.; Assunção, A. Precarious working conditions and health of metropolitan bus drivers and conductors in Minas Gerais, Brazil. Am. J. Ind. Med. 2019, 62, 996-1006. [CrossRef]

36. Yosef, T.; Belachew, A.; Tefera, Y. Magnitude and Contributing Factors of Low Back Pain among Long Distance Truck Drivers at Modjo Dry Port, Ethiopia: A Cross-Sectional Study. J. Environ. Public Health 2019, 2019, 1-7. [CrossRef] [PubMed]

37. Ghasemi, M.; Khoshakhlagh, A.H.; Ghanjal, A.; Yazdanirad, S.; Laal, F. The impacts of rest breaks and stretching exercises on lower back pain among commercial truck drivers in Iran. Int. J. Occup. Saf. Ergon. 2018, 26, 662-669. [CrossRef] [PubMed] 